\title{
Lumbosacral spina bifida in a case with Pallister-Killian syndrome
}

\section{Lumbosakral spina bifida saptanan Pallister= Killian sendromu olgusu}

Vehap Topcu ${ }^{1 *}$, Esra Şükran Çakar ${ }^{1}$, Abdullatif Bakır ${ }^{1}$, Eyüp Ekici²,

Nuri Danış man²

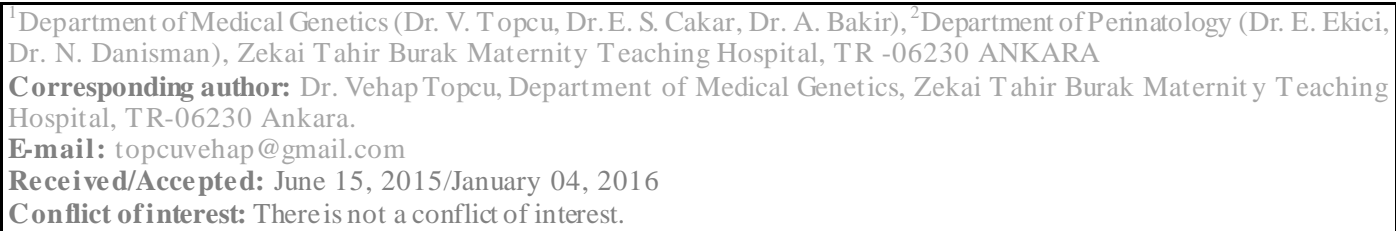

\section{SUMMARY}

Pallister-Killian syndrome (PKS) is a rare disorder caused by tissue limited mosaic tetrasomy of $12 p$. PKS is clinically characterized with facial dysmorphism, mental-motor retardation, hypotonia and internal abnormalities. Most widely seen features include diaphragmatic hernia, rhizomelic upper limbs and cardiac abnormalities. It is diagnosed by means of cytogenetic analysis of amniocytes, chorionic villus, fetal blood lymphocytes or fibroblasts. Cytogenetic analysis of lymphocytes usually shows up normal result. Here, we report a fetus demonstrating irregular vertebral body alignment, omphalocele and left ventricle hypoplasia detected in fetal ultrasonography evaluation of a woman referred to our hospital at 19-week gestational age because of high risk for neural tube defect in second trimester screening test. Cytogenetic analysis was not performed in chorionic villus or amniocytes. The pregnancy was terminated at 20 -week gestational age. PKS was suspected because of the omphalocele and sacral appendage findings in postmortem examin ation. Skin fibroblast culture revealed 47, XY, i (12) (p10) karyotype, confirming the diagnosis. This is the first case of PKS with lumbosacral spina bifida reported. Sacral appendage is a rare finding and reported in few cases. Cytogenetic investigation is the most widely used method to diagnose PKS and is helpful to differentiate PKS from Fryns syndrome that may bear similar clinical findings.

Keywords: Pallister-Killian syndrome, left ventricular hypoplasia, omphalocele, irregularly aligned vertebral bodies, lumbosacral spina bifida, sacral appendage

\section{ÖZET}

Pallister-Killian sendromu (PKS) dokuya özgü tetrazomi 12p ile karakterize nadir bir sendromdur. Klinik olarak fasiyal dismorfizm, mental-motor gerilik, hipotoni ve iç organ anomalileri görülmektedir. Diyafragma hernisi, üst ekstremitelerde rizomelik kisalık ve kardiyak anomaliler en yaygın görülen bulgulardır. Tanı amniyosit, koryon villus, fetal kan veya fibroblast kültüründe yapılan sitogenetik incelemeyle koyulmaktadır. Lenfosit kültüründe yapılan sitogenetik inceleme genellikle normal sonuçlanmaktadır. Burada, ikinci trimester taramasinda nöral tüp defekti açısından yüksek risk saptanması nedeniyle 19. gebelik haftasında hastanemize yönlendirilen kadında yapılan fetal ultrasonografi değerlendirmesinde vertebral kolonda düzensizlik, omfalosel ve sol ventrikül hipoplazisi gözlenen bir olgu sunuldu. Koryon villus veya amniyosit hücrelerinde sitogenetik inceleme yapılmamıștı. Gebelik 20. haftada termine edildi. Postmortem fetal değerlendirmede omfalosel ve sakral apendiks bulgularının gözlenmesi PKS tanısını düşündürdü. Fibroblast kültüründe yapılan sitogenetik incelemenin 47,XY,i(12)(p10) olarak sonuçlanması bu tanıyı doğruladı. Lumbosakral spina bifida ilk defa olgumuzda gözlenmiştir. Sakral apendiks nad ir rastlanan bir bulgudur ve az sayida olguda bildirilmiștir. Sitogenetik inceleme PKS tanısında en yaygin kullanılan metottur ve PKS'nin benzer klinik bulgular sergileyebilen Fryns sendromundan ayırıminda yardımcidir.

Anahtar sözcükler: Pallister-Killian sendromu, sol ventrikül hipoplazisi, omfalosel, düzensiz vertebral korpus dizilimi, lumbosakral spina bifida, sakral apendiks. 


\section{INTRODUCTION}

Pallister-Killian syndrome (PKS) is first defined by Pallister et al. ${ }^{1}$ and Killian and Teschler-Nicola ${ }^{2}$. Tissue limited tetrasomy $12 p$ or $^{3,4}$ more rarely hexasomy $12 p$ is responsible from the etiology of $\mathrm{PKS}^{5,6}$. Cytogenetic analysis of cells obtained from chorionic villi, amniocytes or fetal blood in prenatal term or bone marrow or oral mucosa in postnatal term identifies PKS, whereas peripheral blood lymphocytes usually result in normal cytogenetic constitution $^{7-9}$. Almost all reported cases are sporadic $^{10}$.

Phenotypic spectrum is consisted of diaphragmatic hernia, short upper limbs, increased nuchal translucency, heart defect, urogenital abnormality, omphalocele and hydrops fetalis ${ }^{9},{ }^{11}$. Additional features encountered after birth include mentalmotor retardation and convulsions, increased skin pigmentation, coarse face, sparse hair, flat occipital bone, hypertelorism, short nose, flat nasal bridge, thick philtrum, short neck and imperforate anus ${ }^{9}$, 11, 12. Coarse face, diaphragmatic hernia and acral hypoplasia are common features of PKS and Fryns syndrome, which may cause confusion in differential diagnosis. In this respect, identifying i (12) (p10) in fibroblast culture lets cytogeneticist distinguish PKS from autosomal recessively inherited Fryns syndrome ${ }^{13}$.

Here, we report a 19-week old pregnant woman referred to our hospital with abnormal fetal ultrasonography (irregularly aligned vertebral bodies and omphalocele) and fetal echocardiography (left ventricular hypoplasia) findings. Cytogenetic analysis of fetal skin fibroblasts obtained following termination of the pregnancy showed 47 , XY, i (12) (p10) karyotype constitution.

\section{CASE REPORT}

Fetus was product of the second pregnancy of non-consanguineous healthy parents (26-year-old mother and 29-year-old father). Product of the first pregnancy was a healthy boy, who was five at the time of presentation. Family history was unremarkable. First trimester aneuploidy screening test did not bear any risk, whereas 2 nd trimester screening test indicated possible neural tube defect (NTD), upon which the family was referred to our hospital. Fetal ultrasonography investigation brought out omphalocele and irregularly aligned vertebral bodies (Figure 1a). Fetal echocardiography revealed left ventricular hypoplasia (Figure 1b). Pregnancy was terminated at 20th week of gestation with consent and approval of the parents. Postmortem fetal examination unveiled coarse face, flattening of the facial profile, depressed nasal root, short neck, brachydactyly, omphalocele, lumbosacral spina bifida, sacral appendage and swelling of the dorsal foot (Figure 2a). Cytogenetic analysis of cultured skin fibroblasts explored an extra chromosome, which was thought to be i(12)(p10) (Figure 2b). FISH analysis could not be performed due to we ran out of fibroblast cells. Fetal karyotype was determined as 47, XY, i (12) (p10). Taking together, findings in fetal examination and cytogenetic analysis lead us diagnose the fetus as PKS. Chromosomal analyses of the parents were normal (mother: $46, \mathrm{XX}$, father: $46, \mathrm{XY}$ ). 


\section{CMJ Case Report March 2016, Volume: 38, Number: 1}

Cumhuriyet Medical Journal
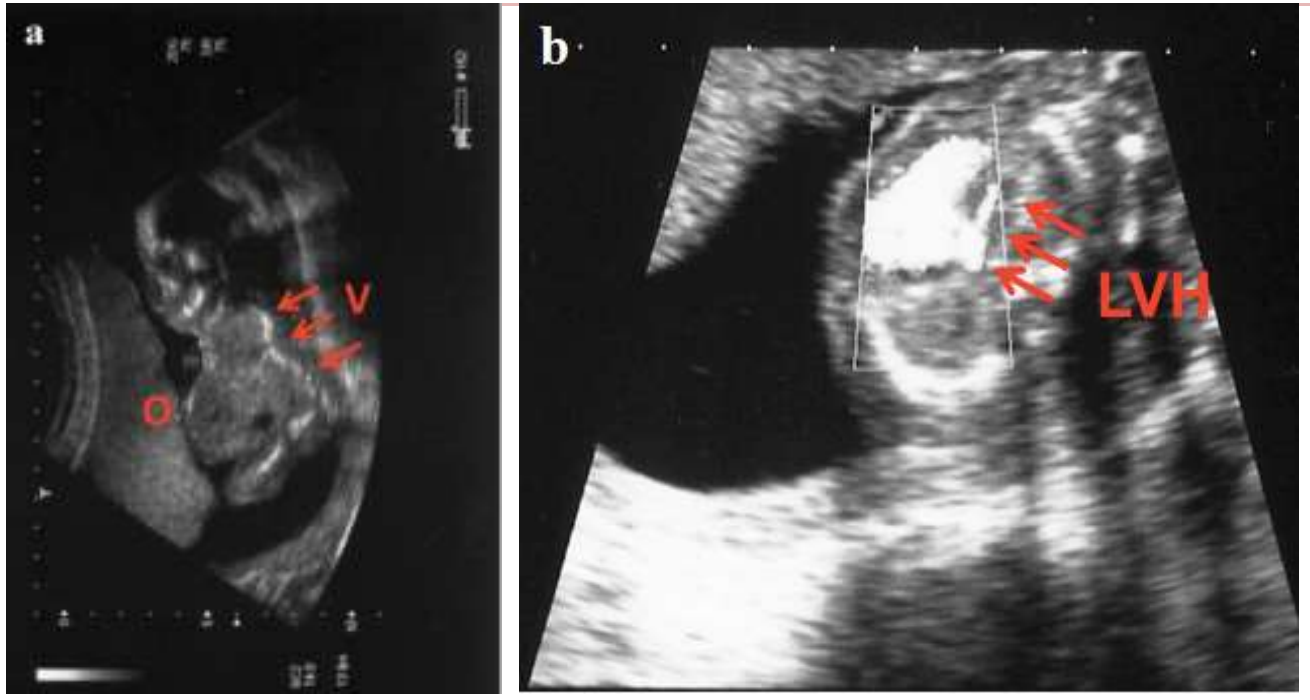

Figure 1 (a, b): Second trimester fetal ultrasonography and fetal echocardiography evaluation a) Omphalocele $(\mathrm{O})$, irregularly aligned vertebral column bodies $(\mathrm{V})$, b) Left ventricular hypoplasia (LVH).

a
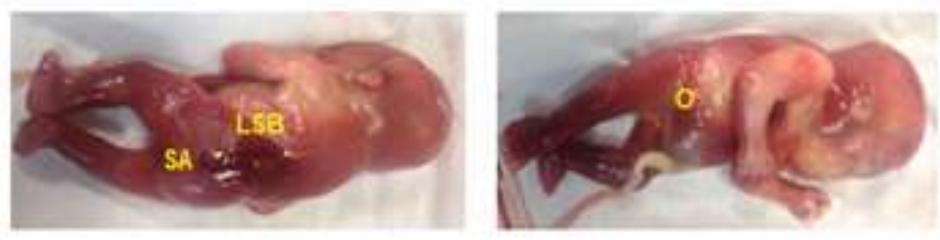

b

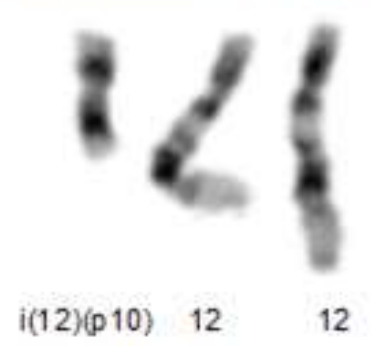

Figure 2 (a, b): Postmortem fetal examination and cytogenetic analysis a) Short neck, omphalocele (O), sacral appendage (SA) and lumbosacral spina bifida (LSB), b) Partial karyotype showing i(12)(p10) detected in cultured skin fibroblasts. Fetal karyotype: 47, XY, i (12) (p10). 


\section{DISCUSSION}

We presented a fetus with i (12) (p10) aberration in skin fibroblasts. This aberration can be deemed as partial tetrasomy 21 erroneously because of its structural resemblance, as well as physical features that may be common between these two cytogenetic abnormalities ${ }^{14}$. Due to unavailability of enough fibroblast cells, we could not rule out this possibility by means of fluorescence in situ hybridization (FISH). However, existence of sacral appendage was supportive of PKS in fetus. Additionally, literature lacks coexistence of sacral appendage and partial tetrasomy 21.

Diaphragmatic hernia, polyhydramnios and risomelic shortening of the extremities are most widely seen abnormalities in prenatal period of PKS. In essence, spectrum of the clinical findings is broader and may include esophageal atresia ${ }^{15}$, cardiac and pulmonary defects, urogenital defects, joint contractures, hydrops fetalis and cerebral ventriculomegaly ${ }^{8,16}$.

First trimester fetal ultrasonography investigation uncovered increased fetal nuchal translucency, diaphragmatic hernia, distinctive facial appearance and risomelic shortening, which were indicative of $\mathrm{PKS}^{17}$.

It is probable to miss the diagnosis in case of normal fetal ultrasonography. Existence of tissue-limited mosaicism of tetrasomy $12 p$ is another obstacle in front of diagnosing PKS. Tissue-limited mosaicism in PKS is thought to arise from cell aging, which results in reduction in number of cells with $\mathrm{i}(12)(\mathrm{p} 10)^{18,19}$. Detection of i (12) (p10) in $100 \%$ of cells obtained from bone marrow of newborns with PKS is supporting that conclusion $^{20}$. In this respect, it is not astonishing to find out $\mathrm{i}(12)(\mathrm{p} 10)$ in all metaphases examined in present case.

Cytogenetic abnormality in PKS is mostly limited to fibroblasts in mosaic form. Relatively slow division rate of fibroblasts in vivo may explain why it is more probable to see i (12) (p10) in these cells. Nevertheless, several weeks that fibroblasts need to grow in vitro may be causing elimination of $i(12)$ (p10) positive cells, which in turn would lead one to conclude the situation as mosaic ${ }^{6}$.
Tetrasomy $12 p$ can easily be detected in oral mucosa or bone marrow cells ${ }^{20}$. Nonetheless, mosaic tetrasomy $12 p$ has been reported in peripheral blood lymphocytes several times ${ }^{21}$. Cytogenetic analysis of chorionic villus or amniocytes provides opportunity to diagnose PKS in prenatal period $^{22}$.

Prenatal diagnosis was not carried out in present case. Obviously, prenatal and postnatal fetal abnormalities bore enough evidence that necessitated cytogenetic analysis be performed in this fetus, which gave us chance to diagnose PKS consequently. Sacral appendage observed in present case is a scarce abnormality, which has been reported in three cases before ${ }^{23}$. Irregularly aligned vertebral bodies and spina bifida has been reported only in this case. On the other hand, spina bifida is an abnormality which may accompany to numerical or structural chromosome abnormalities including trisomy (chromosomes 13, 18, 21), triploidy, unbalanced translocation, marker chromosome and ring chromosome ${ }^{24}$. Cardiac malformations may be a component of PKS, atrial and ventricular septum defects being the most frequent with a frequency of $15 \%{ }^{25}$. Left ventricular hypoplasia detected in present case has been reported once previously ${ }^{11}$. In present case, we observed two scarce findings, omphalocele and sacral appendage. Omphalocele is frequently encountered in chromosomal abnormalities. Together with two previous reports we conclude that it may be an accompanying finding in $\mathrm{PKS}$, too ${ }^{26,27}$. Sacral appendage has been reported in three cases, in which omphalocele was not accompanying $23,28,29$.

As a conclusion, even when cytogenetic investigation of chorionic villus or amniocytes results normal in a fetus with facial dysmorphism or visceral abnormality in fetal ultrasonography screening, it is of critical importance to plan fibroblast culture with respect to identify conditions manifesting tissue limited mosaicism such as PKS. 


\section{REFERENCES}

1. Pallister PD, Meisner LF, Elejalde BR, Francke U, Herrmann J, Spranger J, Tiddy W, Inhorn SL, and Opitz JM. The pallister mosaic syndrome. Birth Defects Orig Artic Ser 1977; 13: 103-10.

2. Killian W and Teschler-Nicola M. Case report 72: Mental retardation, unusual facial appearance abnormal hair. Synd Ident 1981; 7: 6-7.

3. Peltomaki P, Knuutila S, Rit-vanen A, Kaitila I, and de la Chapelle A. Pallister-Killian syndrome: cytogenetic and molecular studies. Clin Genet 1987; 31: 399-405.

4. Warburton D, Anyane-Yeboa K, and Francke U. Mosaic tetra-somy 12p: four new cases, and confirmation of the chromoso-mal origin of the supernumerary chromosome in one of the original PallisterMosaic syndrome cases. Am J Med Genet 1987; 27: 275-83.

5. Vogel I, Lyngbye T, Nielsen A, Pedersen S, and Hertz JM. Pallister-Killian syndrome in a girl with mild developmental delay and mosaicism for hexasomy $12 \mathrm{p}$. Am $\mathrm{J}$ Med Genet A 2009; 149A: 510-4.

6. Choo S, Teo SH, Tan M, Yong $\mathrm{MH}$, and Ho LY. Tissue-limited mosaicism in Pallister-Killian syndrome - a case in point. J Perinatol 2002; 22: 420-3.

7. Antonella V, Pantaleo G, Anna Irma $\mathrm{C}$, Savino $\mathrm{C}$, and Selvaggi $\mathrm{L}$. Pallister-Killian syndrome presenting through nuchal oedema: cytogenetic investigation and parental origin by molecular analysis in a new case. Prenat Diagn 2004; 24 : 229-30.

8. Doray B, Girard-Lemaire F, Gasser B, Baldauf JJ, De Geeter B, Spizzo M, Zeidan C, and Flori E. Pallister-Killian syndrome: difficulties of prenatal diagnosis. Prenat Diagn 2002; 22: 470-7.

9. Park IY, Shin JC, Kwon JY, Koo
BK, Kim M, Lim J, Kim Y, and Han K. Prenatal diagnosis of Pallister-Killian syndrome associated with pulmonary stenosis and right ventricular dilatation. Korean J Lab Med 2009; 29: 366-70.

10. Mathieu M, Piussan C, Thepot F, Gouget A, Lacombe D, Pedes-pan JM, Serville F, Fontan D, Ruffie M, Nivelon-Chevallier A, Amblard F, Chauveau P, Moirot H, Chabrolle JP, Croquette MF, Teyssier M, Plauchu H, Pelissier MC, Gilgenkrantz S, Turc CarelC, Turleau C, Prieur M, Le Mer-rer M, Gonzales M, Journel H, and et al. Collaborative study of mosaic tetrasomy $12 p$ or Pallis-ter-Killian syndrome (nineteen fetuses or children). Ann Genet 1997; 40: 4554.

11. Abad DE, Gabarre JA, Izquierdo AM, Lopez-Sanchez C, GarciaMartinez $\mathrm{V}$, and Izquierdo AG. Pallister-Killian syndrome presenting with a complex congeni-tal heart defect and increased nuchal translucency. J Ultra-sound Med 2006; 25: 1475-80.

12. Lin AE, Clemens M, Garver KL, Wenger SL, and Steele MW. Case of Pallister-Killian syndrome with imperforate anus. Am J Med Genet 1988; 31: 705-7.

13. Veldman A, Schlosser R, Allendorf A, Fischer D, Heller K, Schaeff B, and Fuchs S. Bilateral congenital diaphragmatic hernia: Differentiation between PallisterKillian and Fryns syndromes. Am J Med Genet 2002; 111: 86-7.

14. Slavotinek AM, Chen XN, Jackson A, Gaunt L, Campbell A, Clayton-Smith J, and Korenberg JR. Partial tetrasomy 21 in a male infant. J Med Genet 2000; 37: E30.

15. Bartsch O, Loitzsch A, Ko-zlowski $\mathrm{P}$, Mazauric ML, and Hickmann G. Forty-two supernumerary marker chromosomes (SMCs) in 43,273 prenatal samples: chromosomal distribution, clinical find- 
ings, and UPD studies. Eur J Hum Genet 2005; 13: 1192-204.

16. Langford K, Hodgson S, Seller M, and Maxwell D. Pallister-Killian syndrome presenting through nuchal translucency screening for trisomy 21. Prenat Diagn 2000; 20: 670-2.

17. Mourali M, El Fekih C, Dimassi $\mathrm{K}$, Fatnassi A, Zineb NB, and Oueslati B. First trimester diagnosis of Pallister-Killian syndrome in a fetus with suggestive abnormalities. Tunis Med 2010; 88: 666-9.

18. Priest JH, Rust JM, and Fernhoff PM. Tissue specificity and stability of mosaicism in PallisterKillian +i(12p) syndrome: relevance for prenatal diagnosis. Am $\mathbf{J}$ Med Genet 1992; 42: 820-4.

19. Polityko AD, Goncharova E, Shamgina L, Drozdovskaja N, Podleschuk L, Abramchik E, Jaroshevich E, Khurs O, Pisarik I, Pribushenya O, Rumyantseva N, and Naumchik I. Pallister-Killian syndrome: rapid decrease of isochromosome $12 p$ frequen-cy during amniocyte subculturing. Conclusion for strategy of prenatal cytogenetic diagnostics. J Histochem Cytochem 2005; 53: 361-4.

20. Ward BE, Hayden MW, and Robinson A. Isochromosome 12p mosaicism (Pallister-Killian syndrome): Newborn diagnosis by direct bone marrow analysis. Am $\mathbf{J}$ Med Genet 1988; 31: 835-9.

21. Raffel LJ, Mohandas T, and Rimoin DL. Chromosomal mosaicism in the Killian/TeschlerNicola syndrome. Am J Med Genet 1986; 24: 607-11.

22. Soukup S and Neidich K. Prenatal diagnosis of Pallister-Killian syndrome. Am J Med Genet 1990; 35: 526-8.

23. McLeod DR, Wesselman LR, and Hoar DI. Pallister-Killian syndrome: additional manifestations of cleft palate and sacral appendage. J Med Genet 1991; 28: 541-3.

24. Rose NC and Mennuti MT. Maternal serum screening for neural tube defects and fetal chromosome abnormalities. West J Med 1993; 159: 312-7.

25. Tilton RK, Wilkens A, Krantz ID, and Izumi K. Cardiac manifestations of Pallister-Killian syndrome. Am J Med Genet A 2014; 1130-5.

26. Chen CP. Chromosomal abnormalities associated with omphalocele. Taiwan J Obstet Gynecol 2007; 46: 1-8.

27. Tejada MI, Uribarren A, Briones $\mathrm{P}$, and Vilaseca MA. A further prenatal diagnosis of mosaic tetrasomy 12p (Pallister-Killian syndrome). Prenat Diagn 1992; 12: 529-34.

28. Johnstone ED and Jones EA. U1trasound presentation of Pallis-terKillian syndrome with a prominent sacral appendage. Ultrasound $\mathrm{Ob}-$ stet Gynecol 2012; 40: 239-41.

29. Chaouachi S, Ben Hamida E, Ennine I, Chaabouni M, Sfar R, Chaabouni $\mathrm{H}$, and Marrakchi $\mathrm{Z}$. Pallister-Killian syndrome with additional manifestations of cleft palate and sacral appendage. Tunis Med 2010; 88: 614-6. 